\title{
The Determination of Biology Teacher Candidates' Mental Models and the Misconceptions Related to Catabolism and Anabolism by Drawing-Writing Technique
}

\author{
Selda Kilıç ${ }^{1}$ \\ ${ }^{1}$ Necmettin Erbakan University, Ahmet Keleşoğlu Education Faculty, Department of Biology Education, Konya, \\ Turkey
}

Correspondence: Selda Kılıç, Necmettin Erbakan University, Ahmet Keleşoğlu Education Faculty, Department of Biology Education, Konya, Turkey. E-mail: seldakilicbio@gmail.com

Received: June 14, 2019

Accepted: June 28, 2019 Online Published: October 2, 2019

doi:10.5539/hes.v9n4p71

URL: https://doi.org/10.5539/hes.v9n4p71

\begin{abstract}
The aim of this study is to determine the mental models and misconceptions used by biology teacher candidates in conceptualizing catabolism and anabolism concepts. For this purpose, the study has been conducted voluntarily on 59 biology teacher candidates in 2018-2019 academic year spring semester. In the study, two open-ended questions have been addressed to the students about the concepts of catabolism and anabolism, asking them to make explanation by drawing and writing technique. After the application, students' mental models and also misconceptions about the subject have been determined by analyzing students drawings and explanations. According to the results obtained from students' drawings and explanations, it has been determined that biology teacher candidates have imperfect knowledge and misconceptions about catabolism and anabolism and solution offers have been presented.
\end{abstract}

Keywords: mental models, catabolism, anabolism, drawing-writing technique, biology teacher candidates

\section{Introduction}

Under the name of metabolism, the concepts of catabolism and anabolism are used in different fields such as biology, medicine, agriculture, veterinary medicine, chemistry, physical education and different similar fields. According to Turkish Linguistic Society, all of the chemical events in the living organism that have constructive and destructive feature and all of the events related to assimilation and disintegration in the protoplasm are described as the whole of catabolism and anabolism.

Anabolism is used to describe the changing of small monomers to big molecules, energy storage, growth and development. Catabolism involves the converting of big molecules into monomer (hydrolysis) and the event of obtaining usable energy in the cell by creeping of some monomer into the respiratory reactions (Yel, Bahçeci \&Yılmaz, 2009). Aktümsek, Ünsal \&Kalyoncu (2001) stated that the anabolism and catabolism events which are together afterwards of vitality and that the construction could not be occurred without obtaining energy and precursors substances by destruction and all these events are called metabolism. However, the relation of these concepts with other sub-concepts, which are separated under the concept of metabolism, is not given in detail in high school textbooks. Considering the conceptualization of the concepts of catabolism and anabolism mentioned above with both abstract and many other abstract sub-concepts under the concept of metabolism, it can be said that the concept of metabolism will cause problem and cannot be easily understood and conceptualized by students due to their use in daily life. So that how the concepts of catabolism and anabolism, which are the sub-concepts of metabolism, are reflected in the students' minds and how to determine the deficiencies, if available, is the same with the importance of diagnosis in the treatment of a patient.

In students various educations it is seen that a wide variety of data collection tools are used to determine mental models and misconceptions. Of these, word association test and drawing writing techniques are some of the common techniques. Drawing technique is widely used in terms of expressing opinions about a concept in various fields and revealing mental model, image and misconceptions, if available. For writing and drawing technique, Ormanc1 and Balım (2014) stated that this technique is an alternative method for the students reveal their ideas about any subject. It has been also stated that this method gives students the opportunity to put 
forward the level of understanding about any subject, concept and situation without any limitation. Shepardson, Wee, Priddy \& Harbor (2007) stated that how students conceptualize the concept of environment by being allowed to explain their own words by drawing about the environment. In addition, it has been stated that this written answer or explanation part allowed the validation of the meaning structured from the students' drawings and as a result it has been reflected that how students' conceptual models have been changed and improved by their mental models. Ültay, Dönmez Usta \& Durmuş (2017) analyzed 33 national studies (14 articles, 17 master's thesis and 2 doctoral thesis) on mental model in the field of education with descriptive content analysis. In this study, it has been indicated that the drawings are used much more as data collection tool.

In addition, when the data of analyzed studies reasons were examined, it was found that the most frequency is the determination of mental models before education and the realization of meaningful learning. As a result of the study, they stated that mental models suitable for scientific information are not formed and consequently this conformation is due to lack of teachers, students and education programs in the teaching process. Jalmo and Suwandi (2018) tried to identify mental models. As a consequence, they stated that drawing technique could be used in determining the points which are difficult to learn misconceptions in genetics. Kurt (2013), used drawing and writing techniques on biology teacher candidates to reveal the cognitive structure of immunity which was related to the use of the word association and drawing-writing technique together.

In his study, Ahi (2016) used the technique of drawing explanation to indicate students's mind models about the desert concept. Güneş and Güven (2011) in their study, carried out on 762 high school students, answering the question of "what is the name of the production reactions seen in living things?", they stated that the percentage of the answers was low and the students mixed the terms of anabolism, catabolism, metabolism and basal metabolism.

Biology science is a science in which the abstract concepts are intense. Therefore, Atasoy, Kadayıfçı \&Akkus (2007), stated that these concepts can be learnt and dreamed about by associating to each other and making sense of them and the students will have higher quality images. Since biology science is abstract and difficult to understand, drawing-writing is an appropriate technique to know what students understood, and it is stated in the studies given in the literature. Nugraha (2018) stated that the drawing, which is a painting action, is the oldest data recording technique in science. Besides the above mentioned literature, drawing and writing technique has been used in different areas to reach the students' mental structures in-depth (Kurt, Ekici, Aktas \& Aksu, 2013; Cengiz \& Ekici, 2016). Determining mental models is also a way of identifying students' misconceptions about concepts. Tekkaya (2002) stated that the misconception studies show that students have significant misconceptions about the concepts of biology and these misconceptions need to be identified. Hamdiyati , Sudargo, Redjeki \&Fitriani (2017) in their study on microorganisms stated that the students reflect their mental models related to the virus in their drawings explanation part. It is supposed that the reason is that the students use the pictures during junior high school to explain microorganisms.

The aim of this study is to determine the mental models and misconceptions used by biology teacher candidates in conceptualizing catabolism and anabolism concepts. The problems and sub-problems of this study are as follows:

What are the students' mind models and misconceptions about catabolism and anabolism?

1- What are the mental models of biology teacher candidates about catabolism?

2- What are the mental models of biology teacher candidates about anabolism?

3- What are the misconceptions of biology teacher candidates about catabolism?

4- What are the misconceptions of biology teacher candidates about anabolism?

\section{Method}

\subsection{Research Model}

Qualitative research method has been used in this study. In other words, factors related to a situation (environment, individuals, events, processes, etc.) have been investigated with a holistic approach and focus on how they affect the situation and how they are affected (Yıldırım \& Şimşek, 2011).

\subsection{Research Population}

The catabolism and anabolism study group of this study has been applied on 59 biology teacher candidates who continue their education in Necmettin Erbakan University, Ahmet Keleşoğlu Faculty of Education, Biology education in Konya province at 2018-2019 academic year spring semester. The students were Biology 1, 2, 3 and 4th grade students studying in department of biology education. The students have been included in the study 
due to receive education on catabolism and anabolism within the scope of General Biology 1 course.

These students consisted of 46 female and 13 male students. Participation of the students in the study has been based on voluntariness. The students have been asked to respond by using A4 papers on which they would draw and explain in the natural environment without any change within 1 course hour.

\subsection{Data Collection}

The data collection method used in the study has been determined by considering the purpose of the study. The aim has been selected on behalf of drawing and writing techniques due to reveal of teacher candidates' perceptions about the catabolism and anabolism concepts. The students have been asked to draw 2 open-ended questions and to make an explanation about this drawing. These questions were as "Draw the image of catabolism concept in your mind and write an explanatory sentence or sentences about this concept, and draw the image you have in mind about the concept of anabolism and write an explanatory sentence or sentences about this concept". Students' drawings lasted one course hour. In the process of data collection, from the point of study ethics, volunteerism has been stated to the students as the basis for whether or not participating in the study before joining. After this statement, one student did not want to participate and was not included in the application. The students have been given one class hour and the risk of quick completion or lengthening according to their wishes has been avoided.

\subsection{Data Analysis}

First of all, the papers taken from the students have been marked from 1 to 59 , as S1, S2, .. S59. After that, coding framework has been used to categorize the mind models revealed from the students' drawings and explanations. For the coding framework given in Table 1, Yayla and Eyceyurt (2011) and Hamdiyati et al. (2017) studies have been utilized. In order to calculate the frequencies of mental models related to the concepts of catabolism and anabolism the template used by Jalmo ve Suwandi (2018) was used.

In the analyzes, the drawings have been shown with the letter $\mathrm{D}$ and explanations have been indicated by $\mathrm{W}$ and their levels have been given as numbers beside of each. The students have been asked to answer the open-ended question about given concepts. Before constructing mental models which occurred according to the answers of the questions forwarded to the students about catabolism and anabolism, the issue has been asked from 2 faculty members specialized in Biochemistry and one faculty member specialized in Biology education and therefore the framework of expected answers has been occurred. Moreover, the students have been told by the researcher that they could present their mental models in the form of concept maps, flowcharts, chemical formulas, and pictures. The students have been informed about techniques such as flow chart and concept map. The usage of expressions between concepts and relationships was frequently repeated while drawing concept maps. In this study, students' mental models are shown as an example in Figure 1-10 by being included directly into the study. In addition, in order to ensure the reliability of the study, students' drawings have been examined in a way that they were not affected from each other and the decision was made in terms of objective scoring.

Directed open-ended questions to students;

1- Draw the image of catabolism concept that you have in your mind and write explanatory sentence or sentences about it.

2- Draw the image of anabolism concept that you have in your mind and write explanatory sentence or sentences about it.

After completing study analysis, tables and figures have been added to the findings. Additionally, students' drawings have been added directly to the study to increase the reliability of the study. In the study, if the students gave correct answer but one feature or example, they would be accepted as level 3 and if they gave correct answer with several features and examples they would be considered as level 4.

Table 1. Coding framework of mental model for drawing-writing test results

\begin{tabular}{lllll}
\hline \multicolumn{2}{l}{ Level } & Coding Framework of Drawing (D) & Drawing & Writing \\
\hline 1 & Level 1 & There is no drawing/writing & D1 & W1 \\
2 & Level 2 & Wrong or irrelevant drawing /writing of question & D2 & W2 \\
3 & Level 3 & Partially correct drawing/writing & D3 & W3 \\
4 & Level 4 & The drawing/writing that has some deficiencies & D4 & W4 \\
5 & Level 5 & Completely correct and complete drawing/writing & D5 & W5 \\
\hline
\end{tabular}




\section{Results}

Mental models related to catabolism and anabolism concepts have been presented in Table 2, Table 3, and Figure 1,10 according to the analysis of the data obtained by using drawing and writing technique. In accordance with Table 2, D2 has been presented as drawing and W3 as explanation in terms of catabolism concept. Here, in the explanations which represented by W3 about catabolism concept, the students have stated that small molecules form large molecules. However, most of the students have indicated that maltose was converted to glucose and some have notified that the protein is transformed into amino acids, and some remarked that that maltose transformed into glucose. Some students stated that the respiratory event is catabolism. However, if students did not mention water use or enzyme use in these cases, they have been evaluated as W3. It means that students have partial knowledge. In W4, for example, students could give examples for hydrolysis event. They also mentioned that enzymes were used by using water. So with a few shortcomings, the students could write the definition of catabolism and the structures that have been used. In the D4 drawings, the students have showed their drawings with a few shortcomings. However, non of the students have showed any equation using chemical formulas in the D3, D4 and D5 drawings. Here they have made drawing (D3) by writing the name of monomers and polymers. However, in D2, students have showed only by drawing the monomers as rounds and drawing the polymer as larger. Mostly, mental models have been appeared in chemical equation drawings. The students who named monomers and polymers correctly and indicated the use of the enzyme and addition of water by an appropriate example, have been considered as D5. Moreover, the students who expressed catabolism with a suitable example in parallel with the D5 drawings, have been accepted as W5.

Table 2. Students Frequency Related to Catabolism and Anabolism Concepts

\begin{tabular}{llllllll}
\hline Concept & Level & W1 & W2 & W3 & W4 & W5 & Total \\
\hline Catabolism & D1 & 2 & 1 & 1 & - & - & 4 \\
& D2 & 1 & 7 & 18 & 1 & - & 27 \\
& D3 & - & 2 & 15 & 3 & - & 20 \\
& D4 & - & - & - & 3 & 1 & 4 \\
& D5 & - & - & - & - & - & - \\
& Total & 3 & 10 & 34 & 7 & 1 & 55 \\
Anabolism & D1 & 2 & 2 & - & - & - & 4 \\
& D2 & 3 & 8 & 17 & - & - & 28 \\
& D3 & - & 1 & 16 & - & - & 17 \\
& D4 & - & - & 1 & 9 & - & 10 \\
& D5 & - & - & - & - & 1 & 1 \\
& Total & 5 & 11 & 34 & 9 & 1 & 60 \\
\hline
\end{tabular}

In Table 2, frequency density (f: 15) was determined at most D2W3 (f: 18) and then in D3W3 category related to catabolism concept. It is observed that students have a misconception in their drawings at D2W3 but there is a deficiency in terms of more than 2 dimensions concept in (Figure 1, 2 and 3). With respect to anabolism concept, students frequency density has been determined in the category of D2W3 (f: 17) and then in D3W3 (f: 16) (Figure 6,7 and 8).

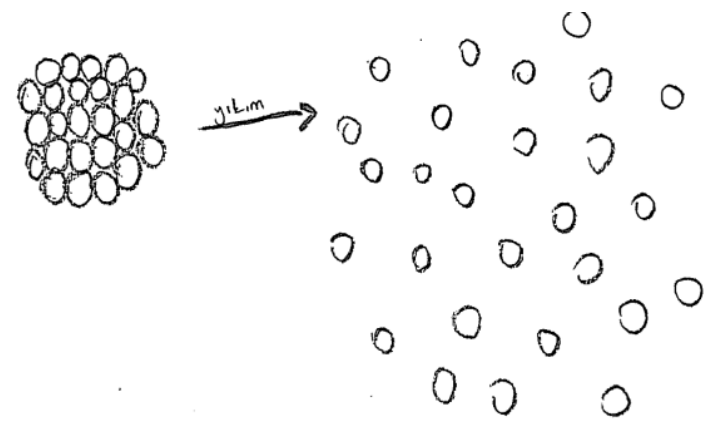

Figure 1. Student mental model related to catabolism (D2) 


$$
\begin{aligned}
& \mathrm{C}_{6} \mathrm{H}_{22} \mathrm{O}_{6} \longrightarrow 2 \mathrm{C}_{6}+2 \mathrm{H}_{12}+2 \mathrm{O}_{6}
\end{aligned}
$$

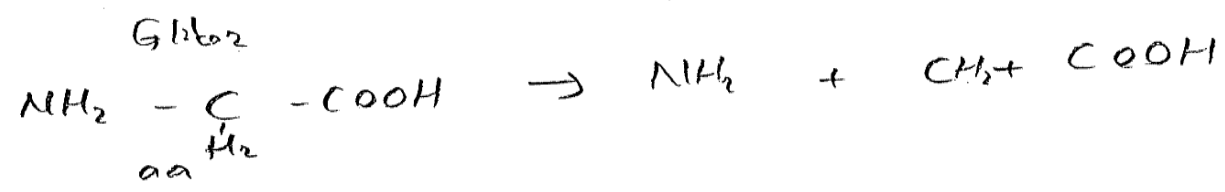

Figure 2. Student mental model related to catabolism (D2)

In Figure 1, the student commented that the concept of catabolism was divided into small pieces. However, it does not express the direction in which it contains a chemical phenomenon. In other words, the student did not state that the enzyme was used. In Figure 2, the student tried to explain the glucose as a respiratory event, but the student wrote the reaction incorrectly.

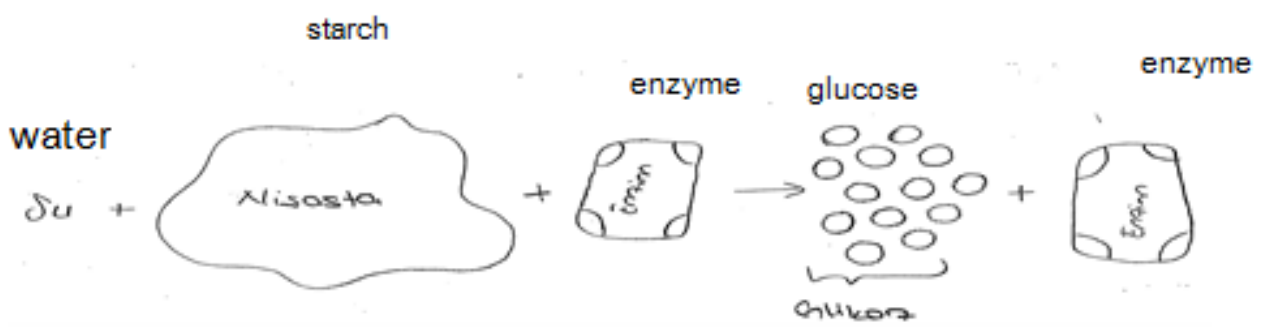

Figure 3. Student mental model related to catabolism (D3)

In Figure 3, the student expressed the transformation of starch to glucose as hydrolysis in his drawings. However, the student by using the concepts of water and enzyme has stated that a polymer has been transformed into a monomeric structure but it has not been able to fully correlate the enzyme and substrate relationship.

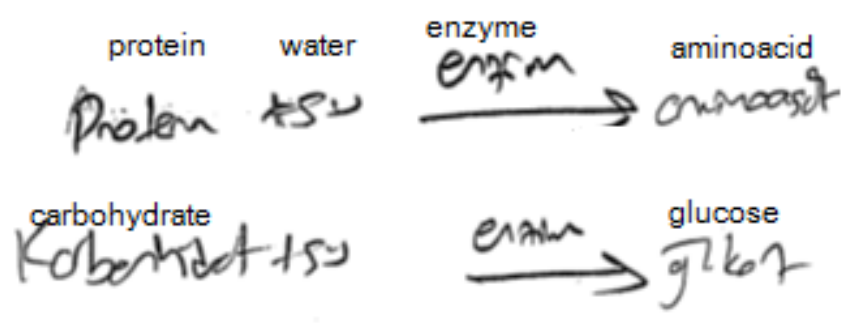

Figure 4. Student mental model related to catabolism (D4)

In this drawing, the student gave protein and carbohydrates as example and stated that they used water and enzyme. But they could not write in detail (Figure 4). 


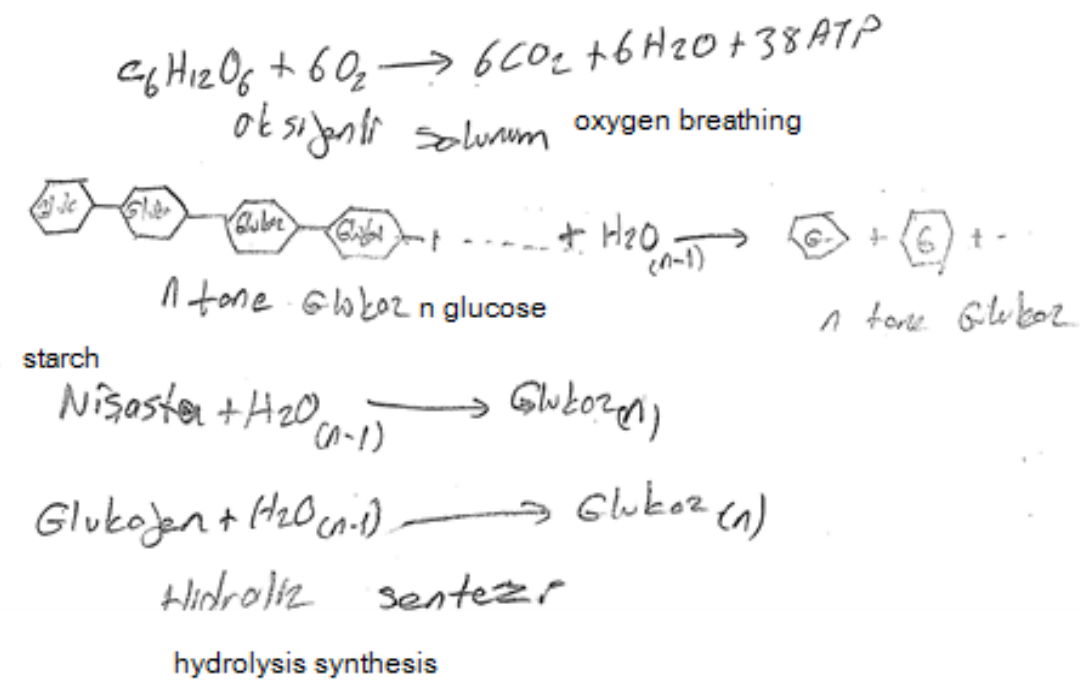

Figure 5. Student mental model related to catabolism (D4)

Here, since the students have drawn the glucose as chemical event and the examples they gave are more than 2 and they used the concept of hydrolysis and water, However, enzyme use in the drawing has not been shown it is considered to be as D4.

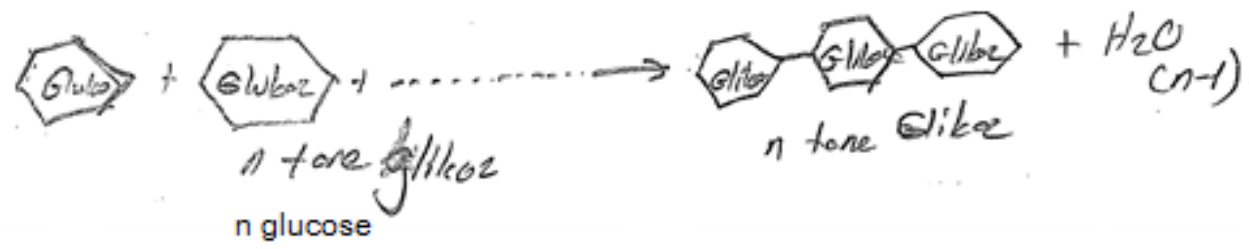

Figure 6. Student's mental model related to the anabolism Concept (D3)

In this drawing, it was stated that the conversion of glucose monomer to starch which is a polymeric structure, is approvended as dehydrated and water is released in this reaction. However, ATP energy and enzyme use in the drawing has not been shown. So it was accepted as D3.

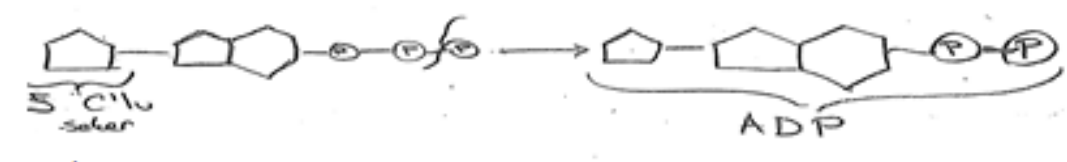

5 carbon sugar

Figure 7. Student mental model related to the anabolism concept (D2)

In Figure 7 and 8, there are deficiencies in terms of student misconception and dimensions of concepts. In Figure 7, the student indicated the ATP pattern by drawing a shape. However, since the transformation to ADP has been drawn as anabolism and there are misconceptions, it is accepted as D2.

$$
\mathrm{CoH}_{2} \mathrm{O}_{6}+\mathrm{CO}_{2} \longrightarrow 6 \mathrm{O}_{2}+\mathrm{isi}^{\text {heat }}
$$

Figure 8. Student mental model related to the anabolism concept (D2) 
In figure 8 . the drawing about anabolism concept, there is a misconception.

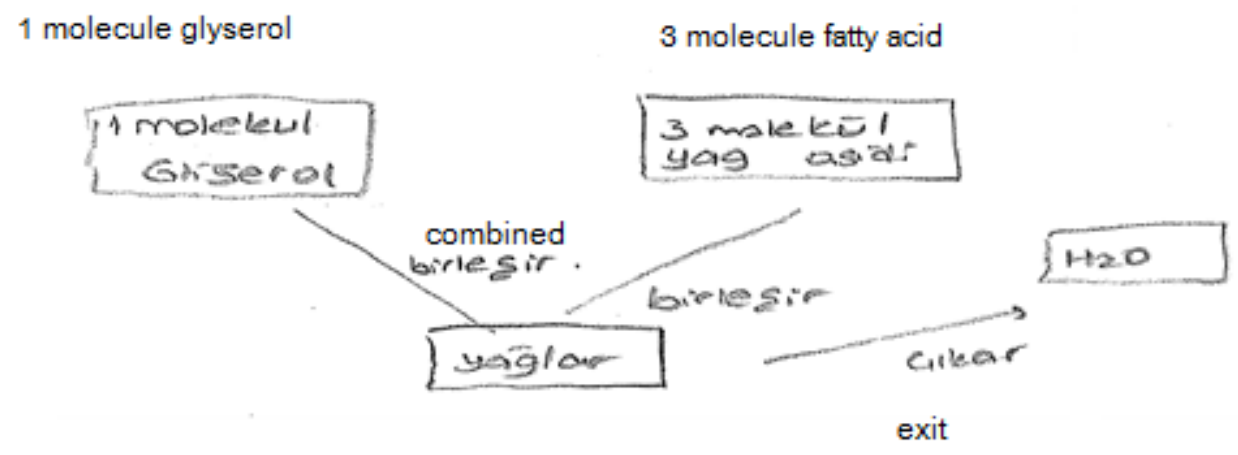

Figure 9. Student mind model about Anabolism Concept (D4)

Figure 9 shows the water release. A student used a simple concept map. However, since the student did not show the effect of the enzyme it was accepted as D4.

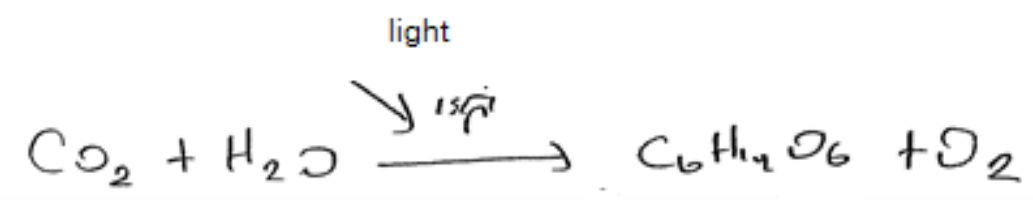

Figure 10. Student mental model related to the anabolism concept (D3)

In Figure 10, the student gave the photosynthesis event as anabolism. However, it did not indicate the relationship between enzyme and ATP. Therefore, it was evaluated in D3 category.

Table 3. Student's mental models

\begin{tabular}{|c|c|}
\hline Concept & Student's Mental Models \\
\hline Cata & $\begin{array}{l}\text { It is the separation of the polymer structures into the smallest monomers in living creatures (W3: } \\
61.82 \%) \text {. Energy in living organisms is the conversion of large structures into small molecules } \\
\text { with enzymes, water and ATP. Catabolism is an example of digestion (W5: } 1.82 \%) \text { which is a } \\
\text { removal of substances that are not beneficial to the body (W2: } 18.18 \%)\end{array}$ \\
\hline An & $\begin{array}{l}\text { Formation of complex larger structures from small molecules (W3: 56.67\%). It is a structure } \\
\text { event like photosynthesis and ATP synthesis that make use of energy and enzymes, and the } \\
\text { formation of large structures from small molecules (W5:1.67\%).Blood clotting is an example for } \\
\text { anabolism (W2: } 18.33 \%) \text {. Monomer structures make larger structures with the help of enzyme, } \\
\text { maltose synthesis (W4: 15\%). }\end{array}$ \\
\hline
\end{tabular}

\section{Misconceptions that are revealed by students' drawings and explanations}

$\mathrm{S} 3-\mathrm{O}_{2}+$ water + mineral $\rightarrow \mathrm{CO}_{2}+$ water (Anabolism)

S8- Food disintegration occurs with respiration and the respiratory event is catabolism.

S8- The energy released after food breaks down (ATP) is an anabolic event.

S3-Catabolism is the process of removing substances from the body that are not necessary.

$\mathrm{S} 2-\mathrm{C}+\mathrm{O}_{2} \rightarrow \mathrm{CO}_{2}+\mathrm{isl}$ (catabolism)

$\mathrm{S} 2-\mathrm{C}_{6} \mathrm{H}_{12} \mathrm{O}_{6}+\mathrm{CO}_{2} \longrightarrow 6 \mathrm{O}_{2}+\imath \mathrm{sl}$ (Anabolism)

The students used the mental model in the form of chemical equation related to both catabolism and anabolism concepts. While writing chemical equations, they showed the names of monomer and polymer structures in Turkish. None of the students stated the chemical reaction by using a detailed chemical formula. They have used more superficial expressions. Apart from that, the students mostly presented their small rounded shapes as 
monomer and larger round shapes ad polymer structure. The students who include the respiratory event in their catabolism drawings mostly showed oxygen intake and carbon dioxide release.

\section{Discussion}

In this study, it is tried to find out how the students conceptualize the concepts of anabolism and catabolism in their minds and their mental models that are the reflection of this conceptualization, and also students' misconceptions about this subject if available. The study was carried out on 59 biology teacher candidates. The concepts of catabolism and anabolism are the basic concepts of biology and indeed a chemistry-based concept.

According to the coding given in Table 1, the concept of catabolism have been mostly seen in D2W3. The students neither use catabolism concept in their D2 drawings nor any explanatory state for catabolism concept. They also made drawings containing wrong concept. In W3 explanations the students stated that catabolism is transformation of large molecules into small molecules. However, here the student perceived all catabolism events as the same catabolic reaction as the conversion of starch to glucose. The students explained the conversion of starch to glucose as respiratory event but some of the students did not express the use of enzymes in these events. In the D3W3 drawings, students expressed the transformation of polymer structures into monomers by drawing and writing. However, some students did not include concepts such as enzymes and water. Therefore, it can be clarified that students have a partial understanding. Tekkaya, Çapa \& Yılmaz (2000) in their study on biology teacher candidates' misconceptions about biology basic concepts, stated that the students could write the chemical formula of the respiration but they ignored energy release. In this study, Figure 2 shows that students have misconceptions about respiratory formula and energy release.

Regarding anabolism concept, D2W3 was the most common. Here again, as in catabolism concept, students have also made drawings in D2 with the exception of anabolism or misconception. In W3 explanations, small monomer structures have been transformed into a polymer structure. They included starch synthesis from glucose. Beside some of students who stated this event as dehydration reaction and water release, there were some others who have not found water and enzymes in this event. This explanation is also considered as W2 if the photosynthesis event is exemplary of the anabolism reaction and dehydration. Again regarding anabolism concept while describing the photosynthesis event, even if the students did not state that it was a construction event and enzyme was used in this event, it was accepted as W3. The thoughts such as "ATP is not consumed in catabolism reactions, but it is consumed in anabolism" is seen as prevailing.

Güneş and Güven (2011) In their study, carried out on 762 high school students, answering the question of "what is the name of the production reactions (anabolism) seen in living things?", they stated that the percentage of the answers was low and the students mixed the terms of anabolism, catabolism, metabolism and basal metabolism. Likewise, it is seen that the students have imperfect knowledge about these concepts. It is seen that students gave examples of anabolism and catabolism events which are sub-concepts of metabolism, but students confused these abstract and functional events and they did not understand hydrolysis event as a catabolism sub-concept. Because students did not use the concept of catabolism and hydrolysis so much in their drawings and explanations and they couldn't correlate these concept (Table 2, Table 3, Figure 1, 2). Sinan et al. (2006), in their study with science teaching students stated that "dehydration is the reaction that occurs when the peptide bonds between proteins break." They stated also that the students have the most misconception like "when the bonds are broken, the cell loses water and gives out the water". In Figures 7 and 8, students have misconceptions in their drawings that they drew dehydrate as an example of anabolism.

From the drawings and explanations it is seen that students often give examples of starch and protein structures and they couldn't comprehend that these events are dehydration reactions and water will release for sure and energy is used in these events.

The students mostly portrayed cognitive structures related to mental models and catabolism and anabolism concepts. However, they could not express this with a chemical process and chemical equations. However, the chemical equations in anabolism and catabolism reactions in drawings have been found with deficiency. Kurt, (2013); Atasoy, Kadayifci \& Akkuş (2007); Cengiz and Ekici (2016) reported in their studies that drawing and writing techniques provide detailed information about students' cognitive structure and can also be used to reveal misconceptions.

These techniques are considered as useful in teaching science education by reflecting students' existing mental models. Students also show that they cannot think of these phenomena, which based on chemical process, the concepts of catabolism and anabolism, which are sub-concepts of metabolism, are seen as deficiencies in biology teacher processes, as principles of chemical reactions. Therefore, it can be said that the concepts of exergonicendergonics in chemistry couldn't be understood by students and also the students should conceptualize 
chemistry subjects as they cannot understand the relationship of ATP, enzyme and water which are construction destruction events.

\section{References}

Ahi, B. (2016). A study to determine the mental models in preschool children's conceptualization of a desert environment. International Electronic journal of Elementary Education, 8(3), 333-350.

Aktümsek, A., Ünsal, S., \& Kalyoncu, L. (2001). Genel zooloji. Nobel Yayın Dağıtım, 1. Basım.

Atasoy, B., Kadayıfçı, H., \& Akkuş, H. (2007). Öğrencilerin çizimlerinden ve açıklamalarından yaratıcı düşüncelerinin ortaya konulması (Çizimler ve Açıklamalar Yoluyla Yaratıcı Düşünceler). Türk Eğitim Bilimleri Dergisi, 5(4), 679-700.

Cengiz, İ. Y., \& Ekici, G. (2016). Biyoloji öğretmen adaylarının laboratuvar kavramına ilişkin görsel imajları. Journal of Research in Education and Teaching, 583.

Güneş, G., \& Güven, T. (2011). Biyoloji öğretiminde yabancı terim sorunu. Türk Eğitim Bilimleri Dergisi, 9(4), 775-798

Hamdiyati, Y., Sudargo, F., Redjeki, S., \& Fitriani, A. (2017). Biology Students' Initial Mental Model about Microorganism. IOP Conf. Series: Journal of Physics: Conf. Series, 812, 012027. https://doi.org/10.1088/1742-6596/812/1/012027

Jalmo, T., \& Suwandi, T. (2018). Biology education students' mental models on genetic concepts. Journal of Baltic Science Education, 17(3), 474-485.

Kurt, H. (2013). Biyoloji öğretmen adaylarının "bağış̧ılık" konusundaki bilişsel yapıları. Dicle Üniversitesi Ziya Gökalp Ĕ̈itim Fakültesi dergisi, 21, 242-264.

Kurt, H., Ekici, G., Aktaş, M., \& Aksu, Ö. (2013). On the concept of “respiration”: Biology student teachers' cognitive structures and alternative conceptions. Global Journal of Education Research, 1(1), 063-083.

Nugraha, I. (2018). The Use of drawing as an alternative assessment tool in biology teaching, 4th International Seminar of Mathematics, Science and Computer Science Education IOP Publishing. https://doi.org/10.1088/1742-6596/1013/1/012016

Ormancı, Ü., \&Balım, A. G. (2014). Ortaokul öğrencilerinin madde konusuna yönelik fikirleri. Elementary Education Online, 13(3), 827-846.

Shepardson, D. P., Wee, B., Priddy, M., \& Harbor, J. (2007). Students'mental models of the environment. Journal of Research in Science Teaching, 44(2), 327-348. https://doi.org/10.1002/tea.20161

Sinan, O., Yıldırım, O., Kocakülah, M. S., \& Aydın, H. (2006). Fen bilgisi öğretmen adaylarının proteinler, enzimler ve protein sentezi ile ilgili kavrama yanılgıları. GÜ. Gazi Eğitim Fakültesi Dergisi, 26(1), 1-16.

Tekkaya, C. (2002). Misconceptions as barrier to understanding biology. Hacettepe Üniversitesi Ĕgitim Fakültesi Dergisi, 23, 259-266.

Tekkaya, C., Çapa, Y., \&Yılmaz, Ö. (2000). Biyoloji öğretmen adaylarının genel biyoloji konularındaki kavram yanılgıları. Hacettepe Üniversitesi Ĕ̈itim Fakültesi Dergisi, 18, 140-147.

Ültay, E., Dönmez, U. N., \& Durmuş, T. (2017). Eğitim alanında yapılan zihinsel model çalışmalarının betimsel içerik analizi. Yaşadıkça Eğitim, 31(1), 21-40.

Yayla, R. G., \& Eyceyurt, G. (2011). Mental models of pre-service science teachers about basic concepts in chemistry. Western Anatolia Journal of Educational Science (WAJES). Selected Papers Presented at WCNTSE Dokuz Eylul University Institute, Izmir, Turkey.

Yel, M., Bahçeci, Z., \& Yılmaz, M. (2009). Genel biyoloji. Gündüz Eğitim ve Yayıncılık, Ankara.

Yıldırım, A., \& Şimşek, H. (2011). Sosyal Bilimlerde Nitel Araştırma Yöntemleri, Seçkin Yayıncılık, 71-72, Ankara.

\section{Copyrights}

Copyright for this article is retained by the author(s), with first publication rights granted to the journal.

This is an open-access article distributed under the terms and conditions of the Creative Commons Attribution license (http://creativecommons.org/licenses/by/4.0/). 